\title{
FLOWERING PLANTS PREFERRED BY BUMBLEBEES (BOMBUS LATR.) IN THE BOTANICAL GARDEN OF MEDICINAL PLANTS IN WROCLAW
}

\author{
Aneta Sikora² \\ Paweł Michołap 1,2 * \\ Maria Kelm ${ }^{1}$ \\ ${ }^{1}$ Wrocław University of Environmental and Life Sciences, \\ The Faculty of Life Sciences and Technology, Department of Plant Protection, \\ pl. Grunwaldzki 24a, 53-363 Wrocław, Poland \\ 2 Natura i Człowiek Association, ul. Legnicka 65, 54-206 Wrocław, Poland \\ *corresponding author: pawel.micholap@up.wroc.pl \\ Received: 3 December 2015; accepted: 16 October 2016
}

A bstract

Due to fewer bumblebees in rural areas these days, it is necessary to look for alternative habitats for the active protection of these very important pollinators. The research was carried out in The Botanical Garden of Medicinal Plants, in Wrocław, Poland. In the garden, approximately 2000 plant species were cultivated, of which 185 were visited by bumblebees. Amongst them, 57 plant species were deemed very attractive and were determined to be indicators for 7 bumblebee species. Indicator species for bumblebees ranged between 6 for Bombus pratorum to up to 20 for B. pascuorum. Monarda didyma was an indicator plant to 6 recorded bumblebee species. Other indicator plant species for at least 4 bumblebees species were: Origanum vulgare, Lavandula angustifolia, Rhododendron catawbiense, Phacelia tanacetifolia, and Agastache rugosa. Three bumblebee species were found to forage the most on 11 of the flowering plant species. The biggest group of plants were those which were mostly visited by 1-2 bumblebee species. Amongst all recorded indicator plants, 32\% were native species.

Keywords: bumblebees, gardens, medicinal plants, urban areas

INTRODUCTION

For millions of years, the coevolution of flowers and bees has evolved through interaction. Individual bee species have adapted to certain types of flowers. This is particularly seen when looking at the length of their tongue. At the same time, visual features of flowers have been diversified in order to attract a particular bee species. As a result, the significance of pollinators has been optimised (Jabłoński \& Ruszkowski, 2000). Some of the plants, like Antirrhinum majus L. or Aconitum spp. have adapted to pollination by bumblebees and even exclusively by a certain species (Goulson, 2010a; Pawlikowski et al., 2016). The adaptation generates a close relationship between many plant species and the presence and activity of bumblebees (Corbet et al., 1991).

Bumblebees (Bombus Latr.) belong to the subgroup Anthophila (Hymenoptera: Apoidea). As social insects, they are almost entirely dependent upon plants for food. Throughout the life of the colony, the bumblebees must forage for both nectar and pollen. The presence of flowering plants is, therefore, a necessity for bumblebee colony growth. However, a decline in bumblebee abundance and species richness has been observed for over 30 years (Goulson et al., 2005; Peters, 1972; Potts et al., 2010; Pawlikowski \& Pawlikowski, 2012; Rasmont et al., 2015). This decline indicates a disturbance in the wildlife corridor. One of the main reasons for this phenomenon are the progressive management changes in rural areas. Those changes have led to the decrease of vegetation; especially a decrease in hay meadows (Goulson, 2010a). There is a possibility of increasing abundance in rural habitats by introducing mixtures of certain plants species, for instance from the Fabaceae family. But because of dangerous levels of pesticide use in agricultural areas, as well as habitat loss, it is essential to find alternative habitats to actively protect the bumblebees. 
Bumblebees appear in different vegetation areas which provide them with adequate food. As such, it is not surprising to find them also in towns and cities. There are places like botanical gardens or urban parks where plenty of flowering plants grow and provide development opportunities for bumblebees like nowhere else. People visiting such places marvel at the beauty of the flowers. Nonetheless, bees perceive flowers differently than humans. If we look at a flower from a bee's perspective, the most beautiful ones are those rich in pollen and nectar. Unfortunately, the native pollinators often find some of the grown and cultivated exotic ornamental plants to be unattractive (Corbet et al., 2001). Many of those flower species are sterile hybrids, which have lost the ability to produce pollen and nectar (Goulson, 2010b).

The concept of indicator plants for bumblebees was created by Ruszkowski (1998a, 1998b). He defines indicators as plants in a particular habitat that are mostly visited by a specific bumblebee species. When considering urban gardens as experiment fields, plants growing there can be examined in terms of their attractiveness to bumblebees. This knowledge could be useful when designing urban green areas and backyard gardens. In addition to their decorative function, such areas can be beneficial food resources for pollinators. The aim of this study was to determine which flower plants are the most attractive for bumblebees as food. The second aim was to define these plants as indicator plants for these insects.

\section{MATERIAL AND METHODS}

The study was conducted in 2011 and 2012 throughout the growing season in the Botanical Garden of Medicinal Plants, at the University of Medicine in Wrocław, Poland. The Botanical Garden is located within the city of Wrockaw. The Garden is separated by the Old and New Odra Rivers and the shipping channels. It is surrounded by residential buildings; sharing a border with a few flat blocks on the Odra River side. Not far away, to the south-east, is Szczytnicki Park. The Botanical Garden of Medicinal Plants began back in 1946. The Garden covers 3.07 ha and is divided into two parts; the park and the garden. Currently, it contains about 2000 species of plants. The details of the Garden's location may be found on Fig. 1.

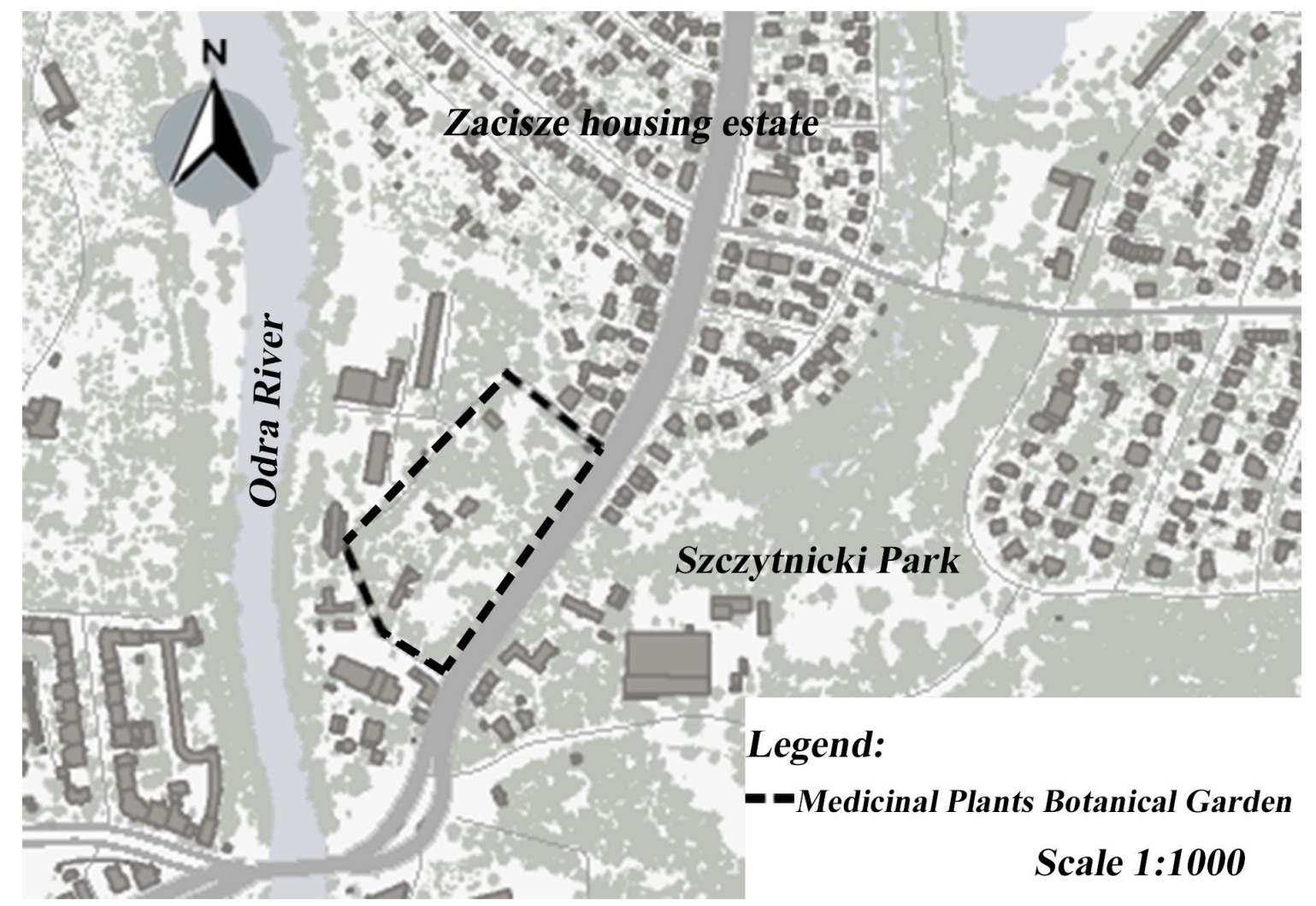

Fig. 1. Location map of Medicinal Plants Botanical Garden. 
Observations were carried out at least three times a week, between 10:00 am and 5:00 pm, when the weather was favourable for the bee activity. The various species of bumblebees were identified by the "intravital method" and then the bumblebees were counted on foraged plant species. The "intravitial method" relies on observations of specimens in their natural habitat and distinguishing them by their appearance, colour patterns etc. without killing them. The doubtful specimens were caught, with the permission issued by the Minister of the Environment, and identified in a laboratory using the dichotomous key (Pawlikowski, 1996). The Bombus terrestris and $B$. lucorum bees were counted together, as distinguishing them is unreliable.

The visited plants and their botanical family membership were recorded. Plant species were divided into the period of bumblebee foraging: spring (March-May), summer (June-August), and autumn (September-October). To determine the most preferred food plants as the indicator ones, a plant had to be visited at least by $5 \%$ of a particular bumblebee species total number.

\section{RESULTS}

In the Botanical Garden of Medicinal Plants, University of Medicine in Wrocław, the occurrence of 7 bumblebee species was observed on 185 flowering plant species. These are the 7 bumblebee species: Bombus hortorum, B. hypnorum, B. lapidarius, B. lucorum, $B$. pascuorum, B. pratorum, $B$. terrestris. For the overall season, the highest number of plants was visited by $B$. terrestris/lucorum - 130 plants, $B$. pascuorum visited the next highest number of plants - 101 plants, B. lapidarius - 86 plants, B. hortorum - 36 plants, B. hypnorum - 12 plants. The least number of plants was visited by $B$. pratorum - 6 plants (Tab. 1).

Among all the visited plant species, 57 were classified as bumblebee indicator plants, which engaged an average of $79 \%$ of bumblebee visits during the vegetation season. In this group 6 plant species were visited by at least 4 bumblebee species, and 8 plants were visited by 3 bumblebee species. The biggest group of

Table 1

The number of food and indicator plants for Bombus spp. during the growing seasons, at the

Medicinal Plant Garden, University of Medicine in Wrocław, Poland, 2011 - 2012

\begin{tabular}{|c|c|c|c|c|c|c|c|c|c|c|}
\hline \multirow{3}{*}{ Bombus sp. } & \multicolumn{3}{|c|}{ Spring season } & \multicolumn{3}{|c|}{ Summer season } & \multicolumn{3}{|c|}{ Autumn season } & \multirow{3}{*}{$\begin{array}{c}\begin{array}{c}\text { Total } \\
\text { no. } \\
\text { of food } \\
\text { plants }\end{array} \\
\text { n }\end{array}$} \\
\hline & \multirow{2}{*}{$\begin{array}{c}\text { Food } \\
\text { plants }\end{array}$} & \multicolumn{2}{|c|}{$\begin{array}{l}\text { Indicator } \\
\text { plants }\end{array}$} & \multirow{2}{*}{$\begin{array}{c}\text { Food } \\
\text { plants }\end{array}$} & \multicolumn{2}{|c|}{$\begin{array}{l}\text { Indicator } \\
\text { plants }\end{array}$} & \multirow{2}{*}{$\begin{array}{c}\text { Food } \\
\text { plants }\end{array}$} & \multicolumn{2}{|c|}{$\begin{array}{l}\text { Indicator } \\
\text { plants }\end{array}$} & \\
\hline & & $\mathrm{n}$ & $\begin{array}{c}\% \\
\text { of visits }\end{array}$ & & $n$ & $\begin{array}{c}\% \\
\text { of visits }\end{array}$ & & n & $\begin{array}{l}\% \\
\text { of visits }\end{array}$ & \\
\hline B. hortorum L. & 2 & 2 & 100 & 33 & 8 & 62 & 4 & 4 & 100 & 36 \\
\hline B. hypnorum L. & 4 & 4 & 100 & 8 & 8 & 100 & - & - & - & 12 \\
\hline B. lapidarius L. & 9 & 9 & 100 & 81 & 6 & 37 & 4 & 4 & 100 & 86 \\
\hline $\begin{array}{l}\text { B. pascuorum } \\
\text { Scop. }\end{array}$ & 15 & 7 & 71 & 79 & 5 & 33 & 23 & 8 & 63 & 101 \\
\hline B. pratorum L. & 2 & 2 & 100 & 4 & 4 & 100 & - & - & - & 6 \\
\hline \multirow[t]{2}{*}{$\begin{array}{l}\text { B. terrestris L. / } \\
\text { B. Iucorum L. }\end{array}$} & 16 & 8 & 77 & 108 & 6 & 40 & 19 & 3 & 74 & 130 \\
\hline & Average & & 91 & & & 62 & & & 84 & \\
\hline
\end{tabular}


Table 2

The list of indicator plant species for Bombus spp. in the Garden of Medicinal Plants, University of Medicine in Wrocław, for particular months

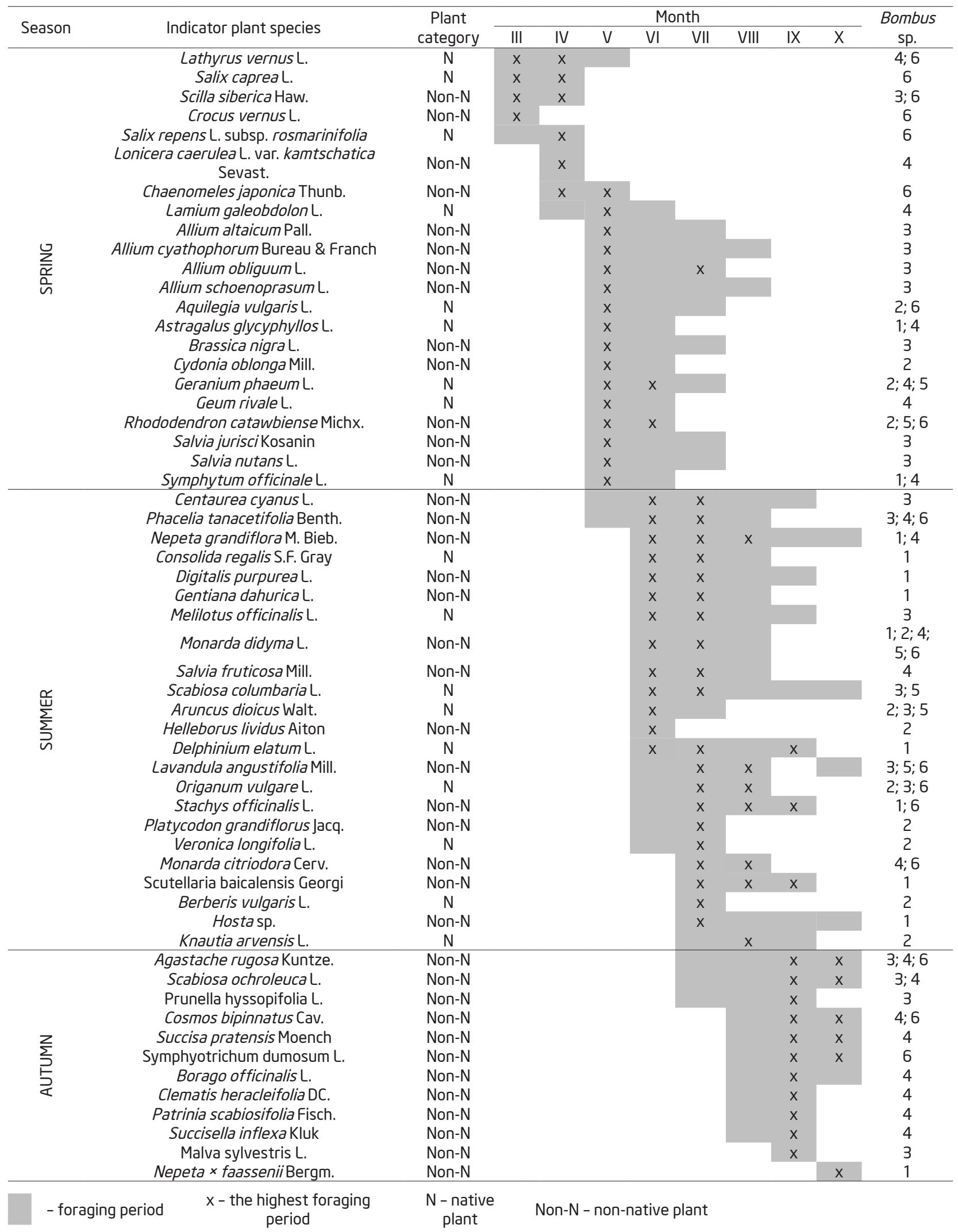

Bombus species: 1 - B. hortorum;2 - B. hypnorum; 3 - B. lapidarius, 4 - B. pascuorum; 5 - B. pratorum; 6 - B. terrestris and B. lucorum;

6? 
these plants were visited by 1-2 bumblebee species. Within the indicator plants, 32\% were native species (Tab. 2).

In the spring period, there were 22 food plant species most attractive for bumblebees and visited by at least 3 bumblebee species. In particular, there were: Geranium phleum, Rhododendron catawbiense, Lathyrus vernus, Scilla siberica, Aguilegia vulgaris. In the summer period, the bumblebees visited the largest number of flowers. The most attractive plants consisted of 23 species, especially: Monarda didyma - visited by 6 bumblebee species, and Phacelia tanacetifolia, Lavandula angustifolia, Origanum vulgare, Monarda Citriodora - visited by at least 3 bumblebee species. In the autumn 12 indicator species were determined, notably: Agastache rugosa, Scabiosa ochroleuca, and Cosmos bipinnatus (Tab. 2).

\section{DISCUSSION}

The research results of bees occurring in European Botanical Gardens show that these sites play an important role for these insects in the cities. A rich food base resulting from the accumulation of a large number of plant species in a relatively small area, is present (Kowalczyk et al., 2004). Comparing the bumblebee species composition in botanical gardens located in Poland (Sikora \& Kelm, 2012; Kowalczyk et al., 2004), Germany (Bembè et al., 2001; Münze, 2006; Steven, 1995; Küpper, 1999), and Switzerland (Augstburger \& Zettel, 2002), it is easy to notice that the results are very similar. The presence of $B$. lapidarius, B. pascuorum, $B$. hypnorum, and $B$. terrestris is not surprising, as they are widespread and common species. The presence of $B$. hypnorum which is associated with woodland habitats, was recorded in all of the studied gardens (Alford, 2011).

The Botanical Gardens have quite a similar species structure, which is probably related to the location of these places. The majority of the gardens are isolated habitats combined with an open landscape by the ecological connectors. Such relationships are confirmed by the surveys of McFrederick et al. (2006), where bumblebees abundance and species richness in urban parks were correlated with the surrounding area, and thus, with lax mobility of specimens. Botanical Gardens in Dresden, Bern, and Munich, despite having a similar location as other botanical gardens, distinguish themselves by the presence of rare bumblebee species and the lack of some commonly occurring bumblebee species. Such a distinction may be associated with food plants and habitat preferences.

The green areas in cities play an extremely importantrole in terms of biodiversity protection. Progressive urbanisation and occupation of areas for construction sites are the main reason for the decline of pollinator biodiversity (Martins et al., 2013). On the other side, flower rich urban areas can provide suitable food for wild bees (Gaston et al., 2005; Hülsmann et al., 2015). Simultaneously, such areas are dominated by exotic and ornamental flower plants, which cause the generalist bee species dominance (Corbet et al., 2001). In particular cases, bumblebees abundance can be significantly higher in urban habitats in comparison to natural ones (Goulson et al., 2002; BanaszakCibicka \& Żmihorski, 2012).

The list of plant species visited by the $B$. terrestris and B. lucorum in the Garden of Medicinal Plants, is extremely long. The list contains 130 plant species. Such an number indicates an ability of the bees to forage on a vast range of flower plants, and also indicates the adaptation of these bee species to food collecting. The food line for these bumblebee species developed by Ruszkowski (1971) differed significantly from the Garden food base. Plants considered by Ruszkowski as the main food base for bumblebees in the Garden were not so important. They were: Trifolium pratense, Helianthus annuus, Echium vulgare, and Tagetes spp. Other plants of this group are mainly crops which were absent in the Garden. For $B$. terrestris and B. lucorum, Ruszkowski (1998a) lists 53 indicator plant species for different months. This list differs from the one developed for the Wrockaw Garden of which there were only 5 species of common ones: Salix caprea, Salix repens, Agastache rugosa, Cosmos 
bipinnatus, and Symphyotrichum dumosum. The bumblebees in the Wrockaw Garden visited decorative plant species, as well as those plants described by Ruszkowski (1998a) as not essential in terms of food sources for those bees, like Stachys officinalis and Phacelia tanacaetifolia.

Ruszkowski \& Biliński (1970) list the most often searched for food of $B$. lapidarius to be in areas without bushes, where the main food plants are flora species of meadows and roadsides. Food plants found by the aforementioned researchers and those occurring in the Garden are characterised by their relative similarity. The Centaurea cyanus was the most frequently and faithfully visited flower plant in the Garden. While Ruszkowski when noting the most frequently visited plant, considers a species of the same genera - Centaurea scabiosa. Differences occur in the case of indicator plants, of which Ruszkowski (1998a) lists 46 species. The common plants for the Wrocław Garden of Medicinal Plants and Ruszkowski's list are only Phacelia tanacaetifolia, Centaurea cyanus, and plants of the genus: Salvia, Lavandula, and Agastache. A high percentage of $B$. lapidarius foraged on different species of Allium which grow in the Wrockaw Garden, as well as Melilotus officinalis, which Ruszkowski (1969c) listed as visited in small numbers.

The indicator plants for $B$. pascuorum (Ruszkowki, 1998b) overlap to a small extent with those occurring in the Wrockaw Garden of Medicinal Plants. Only the spring species like Lathyrus vernus, Galeobdolon luteum and autumn ones: Succisa pratensis and Cosmos bipinnatus are consistent for both lists. For B. pascuorum, Ruszkowski (1969d) lists the food plant species Vaccinium myrtillus, which do not occur in the Wrockaw Garden, or are not often visited: Echium vulgare and Trifolium pratense. In the Wrockaw Garden, B. hortorum was found on 43 plant species. Its long tongue exclusively allows it to collect food from flowers with long floral tubes, and as a result pollinates the flowers. Ruszkowski \& Żak (1969) reported the main food plants to be the species which also grow in the Wrocław Garden: Nepeta spp. and Digitalis spp. Bombus hortorum was seen quite often on these plants. Some species of plants that the author stated are necessary for the bee development represented a small alimentary share in the Wrocław Garden: Lamium album, Stachys officinalis, Delphinium elatum, and Aconitum firmum (a species whose range is closely linked with the occurrence of a $B$. hortorum). The bumblebee was the most frequently observed on Gentiana dahurica, but Ruszkowski lists it as a plant visited sporadically. The Bombus hypnorum was seen only on 12 plant species in the Wrockaw Garden. The main food plants mentioned by Ruszkowski (1969a) are trees and shrubs: Tilia spp., Symphoricarpos Duhamel spp., Spiraea spp., Rubus Spp., and Malus spp., which indicates the presence of this bumblebee in park areas. Such areas provide the bumblebee with an easier way to find food and nesting places.

The differences of the $B$. pratorum are associated with woodland areas. In the Wrockaw Garden, woodland areas appeared the least frequently, and only on 6 plant species. The Ruszkowski (1969b) elaboration, lists the plants that are faithfully and most frequently visited by the bumblebee. Most of the plants on his list do not grow in the Wrockaw Garden: Ribes uva-crispa, Rubus spp., Chamaenerion angustifolium, and those that have already occurred: Knautia arvensis, and Pulmonaria officinalis were not visited by $B$. pratorum. The only plant mentioned by Ruszkowski and visited in the Wrocław Garden is Geranium phaeum, which is marked as visited faithfully and sometimes in large numbers.

Thedissimilarity betweenanumber of Ruszkowski's publications and our studies in the Medicinal Plant Garden, demonstrates the uniqueness of an area where the whole vegetation has been artificially formed by man. Ruszkowski also used a different methodology. He used his own observations and other authors' publications, where reliability was determined based on the amount of reported records of specific bumblebee species on individual plants. In our elaboration, the number of bumblebees on each plant species was used, which determines the 
most willingly visited plants. In all of Ruszkowski studies, the main plant food or a major addition was Trifolium pratense. This plant, despite the fact that it did occur in the Wrocław Garden was reluctantly visited by bumblebees. Probably the main reason could be that there were other attractive neighbouring plants covering a larger area which effectively attracted bees.

Our studies show, based upon bumblebee abundance, that The Botanical Garden has significant advantages and ensures the existence of these insects. During surveys, the most attractive plant species for bumblebees were identified as indicator plants. Amongst them, the native plant species were less attractive than the non-native plants. The knowledge of bumblebee indicator plants can be useful for the active conservation of these threatened species. Non-native plant species might be used for landscape planning in urban areas, due to their decorative properties and attractiveness for bees. However, proposed exotic plants should always be checked for invasiveness, and if invasive, their usage should be discontinued. The most attractive, native plants can be used for bumblebee conservation and reintroduction purposes, especially in semi-natural and natural habitats. To create a list of indicator plants for particular bumblebee species for these habitats, further research needs to be carried out.

\section{REFERENCES}

Alford, D.V. (2011). Bumblebees. Northern Bee Books.

Augsburger, C., \& Zettel, J. (2002). Die Bienenfauna (Hymenoptera, Apidae) im Botanischen Garten Bern (Schweiz). Naturforschende Gesellschaft in Bern, 59, 79-99.

Banszak-Cibicka, W., \& Żmihorski, M. (2012). Wild bees along urban gradient: winners and losers. Journal of Insect Conservation, 16, 331-343. https://doi. org/10.1007/s13592-013-0232-7

Bembè, B., Gerlach, G., Schuberth, J., Schönitzer, K. (2001). Die Wildbienen im Botanisch Garten München. Nachrichtenblatt der Bayerischen Entomologen, 50, 30-41.
Corbet, S.A., Williams, I.H., \& Osborne, J.L. (1991). Bees and the pollination of crops and wild flowers in the European Community. Bee World, 72, 47-59. https:// doi.org/10.1080/0005772x.1991.11099079

Corbet, S.A., Bee, J., Dasmahapatra, K., Gale, S., Gorringe, E., La Ferla, B., Moorhouse, T., Trevail, A., Van Bergen, Y. Vorontsova, M. (2001). Native or exotic? Double or single? Evaluating plants for pollinatorfriendly gardens. Annals of Botany, 87, 219-232. https://doi.org/10.1006/anbo.2000.1322

Frankie, G.W., Thorp, R.W., Schindler, M., Hernandez, I., Ertter, B., Rizzardi, M. (2005). Ecological Patterns of Bees and Their Host Ornamental Flowers in Two Northern California Cities. Journal of the Kansas Entomological Society, 78, 227-246. https://doi. org/10.2317/0407.08.1

Gaston, K., Smith, R., Thomson, K., Warren, P. (2005). Urban domestic gardens (II): experimental tests of methods for increasing biodiversity. Biodiversity and Conservation, 14, 395-413. https://doi.org/10.1007/ s10537-004-6066- $x$

Goulson, D., Hughes, W. H. O., Derwent, L. C., Stout, J. C. (2002). Colony growth of the bumblebee, Bombus terrestris, in improved and conventional agricultural and suburban habitats. Oecologia, 130, 267-273. https://doi.org/10.1007/s004420100803

Goulson, D., Hanley, M.E., Darvill, B., Ellis, J.S., Knight, M.E. (2005). Causes of rarity in bumblebees. Biological Conservation, 122, 1-8. https://doi.org/10.1016/j.biocon.2004.06.017

Goulson, D. (2010a). Bumblebees, Behavior, Ecology and Conservation. Oxford University Press.

Goulson, D. (2010b). Bumblebees. In Silent Summer: The State of Wildlife in Britain and Ireland. (pp. 415429). Cambridge University Press.

Hülsmann, M., Wehrden, H., Klein, A.M., Leonhardt, S.D. (2015). Plant diversity and composition compensate for negative effects of urbanization on foraging bumble bees. Apidologie, 46, 760-770. https://doi. org/10.1007/s13592-015-0366-x 
Jabłoński, B., \& Ruszkowski, A. (2000). Rośliny pokarmowe pszczół. Kraków: Polski Klub Ekologiczny.

Kowalczyk, J. K., Szczepko, K., Kurzac, T., Pawlikowski, T. (2004). Pszczoły (Hymenoptera, Apoidea) Ogrodu Botanicznego w kodzi. In Fauna miast Europy Środkowej 27 wieku. (pp. 67-82) Bydgoszcz: Logo.

Küpper, G. (1999). Wildbienen (Hymenoptera, Apidae) im Siedlungsbereich. Eine Untersuchung der Bienenfauna im Botanischen Garten der Ruhr-Universität Bochum. Natur \& Heimat, 59(2), 45-52.

Martins, A.C., Gonçalves, R.B., \& Melo, G.A. (2013). Changes in wild bee fauna of a grassland in Brazil reveal negative effects associated with growing urbanization during the last 40 years. Zoologia (Curitiba), 3022), 157-176. https://doi.org/10.1590/s198446702013000200006

McFrederick, Q. S., \& LeBuhn, G. (2006). Are urban parks refuges for bumble bees Bombus spp. (Hymenoptera: Apidae)?. Biological Conservation, 129(3), 372-382. https://doi.org/10.1016/j.biocon.2005.11.004

Münze, R., Langner, D., \& NuB M. (2006). Die Bienenfauna des Botanischen Gartens Dresden (Hymenoptera: Apidae). Sächsische Entomologische Zeitschri$f t, 7,45-69$.

Pawlikowski, T. (1996). Klucze do oznaczania owadów Polski cz. XXIV Błonkówki-Hymenoptera. Toruń: Oficyna Wydawnicza Turpress.

Pawlikowski, T., \& Pawlikowski, K. (2012). Trzmielowate Polski (Hymenoptera: Apidae: Bombini). Toruń: Wydawnictwo Naukowe Uniwersytetu Mikołaja Kopernika.

Pawlikowski, T., Olszewski, P., Żyła, W., Przybylińska, M. (2016). The rare oligolectic bumblebee Bombus gerstaeckeri Morawitz, 1882 from Poland. Spixiana 39(1), 130.

Peters, G. (1972). Ursachen für den Rückgang der seltenen heimishchen Hummelarten (Hym., Bom- bus et Psithyrus). Entomologische Berichte, 1972, 85-90.

Potts, S.C., Biesmeijer, J.C., Kremen, C., Neumann, P., Schweiger, O., Kunin, W.E. (2010). Global pollinator declines: trends, impacts and drivers. Trends in Ecology and Evolution, 25(6), 345-353. https://doi. org/10.1016/j.tree.2010.01.007

Rasmont, P., Franzén, M., Lecoca, T., Harpke, A., Roberts, S.P.M., Biesmeijer, J.C., .... Schweiger, O. (2015). Climatic Risk and Distribution Atlas of European Bumblebees. Biorisk, 19(Special Issue).

Ruszkowski, A. (1969a). Rośliny pokarmowe trzmiela parkowego - Bombus hypnorum (L.) i jego znaczenie gospodarcze. Pamiętnik Puławski, 37,321-338.

Ruszkowski, A. (1969b). Rośliny pokarmowe trzmiela leśnego - Bombus pratorum (L.) i jego znaczenie gospodarcze. Pamiętnik Puławski, 37,339-354.

Ruszkowski, A. (1969c). Rośliny pokarmowe trzmiela rudego - Bombus agrorum (L.) i jego znaczenie gospodarcze. Pamiętnik Puławski, 37,385-408.

Ruszkowski, A. (1971). Rośliny pokarmowe i znaczenie gospodarcze trzmiela ziemnego - Bombus terrestris (L.) i trzmiela gajowego - B. Iucorum (L.), Pamiętnik Puławski, 47,215-250.

Ruszkowski, A. (1998a). Rośliny wskaźnikowe dla trzmieli (Bombus Latr.) krótkojęzyczkowych. Pszczelnicze Zeszyty Naukowe, 1, 321-332.

Ruszkowski, A. (1998b). Rośliny wskaźnikowe dla trzmieli (BombusLatr.)długo i średnio języczkowych. Pszczelnicze Zeszyty Naukowe, 1, 333-343.

Ruszkowski, A., \& Biliński, M. (1970). Rośliny pokarmowe trzmiela kamiennika - Bombus lapidarius (L.) i jego znaczenie gospodarcze. Pamiętnik Puławski, 37, 43-60.

Ruszkowski, A., \& Żak, B. (1969). Rośliny pokarmowe i znaczenie gospodarcze trzmieli z podrodzaju Hortorobombus Vogt. Pamiętnik Puławski, 37, 359-384. 
Sikora, A., \& Kelm, M. (2012). Flower preferences of the Wrockaw Botanical Garden Bumblebees (Bombus spp.), Journal of Apicultural Science, 56(2), 2736. https://doi.org/10.2478/v10289-012-0021-y

Steven, M. (1995). Blüten- und Nahrungsangebot des Botanischen Gartens in Münster und das saisonale Auftreten von Bienen (Apoidea). Retrieved July 10, 2015, from http://www.nabu-naturschutzstation-muensterland.de/cms/upload/pdf/Diplomarbeit_Michael-Steven.pdf 
